\title{
Substitusi Tepung Sukun (Artocarpus altilis [Parkinson.] Fosber) sebagai Filler-Binder dalam Bakso Daging Sapi
}

\author{
Substitute for Breadfruit Flour (Artocarpus altilis [Parkinson.] Fosber \\ as a Filler-Binder in Beaf Meatballs
}

\section{Jumriah Syam ${ }^{*}$, Irmawaty ${ }^{1}$ Kasmiyati Kasim²}

${ }^{1}$ Prodi Peternakan, Fakultas Sains dan Teknologi, Universitas Islam Negeri Alauddin Makassar. Kampus II.Jl.H.M.Yasin Limpo No 36, Romang Polong-Gowa- Indonesia Kode Pos 9211; Telp (0411) 841879; Fax(0411) 8221400

*Koresponedensi Email: jumriah.syam@uin-alauddin.ac.id

1 Prodi Peternakan, Fakultas Sains dan Teknologi, Universitas Islam Negeri Alauddin Makassar. Kampus II.Jl.H.M.Yasin Limpo No 36, Romang Polong-Gowa- Indonesia

Kode Pos 9211; Telp (0411) 841879; Fax(0411) 8221400

Email: irmawaty@uin-alauddin.ac.id

2Departemen Sosial Ekonomi, Fakultas Peternakan Universitas Hasanuddin

Jl.Perintis Kemerdekaan Km 10 Makassar-Indonesia

Kode Pos 90245

Email: kasmihirdan@yahoo.co.id

\begin{abstract}
ABSTRAK
Bakso yang memiliki kualitas dan citarasa spesifik disukai oleh konsumen. Kualitas dan citarasa bakso dipengaruhi oleh komposisi dan jenis bahan yang digunakan. Sukun adalah tanaman tropis, berproduksi secara musiman dan memiliki cita rasa yang khas. Sukun tumbuh subur di Indonesia, namun potensi tepung sukun sebagai filler-binder dalam bakso daging sapi belum digunakan secara optimal. Penelitian ini bertujuan mengetahui potensi tepung sukun dan menemukan formulasi terbaik tepung sukun sebagai filler dan binder dalam bakso daging sapi. Penelitian bersifat eksperimental, menggunakan rancangan acak lengkap, yakni 5 perlakuan $(0 \%, 10 \%$, $20 \%$, 30\% dan 40 tepung sukun ) masing-masing 5 ulangan. Paramater uji adalah uji kimia : daya ikat air (DIA), uji fisik : daya lenting dan uji organoleptic: warna. tekstur dan rasa. Analisis data menggunakan Analisis of Variances. Hasil penelitian menemukan bahwa tepung sukun memiliki potensi menggantikan tepung tapioka sebagai filler namun tidak sebagai binder. Tepung sukun sebagai : filler (daya lenting) berpengaruh sangat nyata $(\mathrm{P}<0.01)$; binder (daya ikat air) tidak berpengaruh nyata $(\mathrm{P}>0.05)$. Formulasi terbaik ditemukan pada perlakuan $\mathrm{P}_{4}$ ( $40 \%$ tepung sukun).
\end{abstract}

Kata Kunci: Bakso sapi, filler-binder, tepung sukun (Artocarpus altilis [Parkinson.] Fosberg)

\begin{abstract}
Meatballs that have specific qualities and flavors are preferred by consumers. The quality and flavor of meatballs are influenced by the composition and type of material used. Breadfruit is a tropical plant, produces seasonally and has a distinctive taste. Breadfruit thrives in Indonesia, but the potential for breadfruit flour as a filler-binder in beef meatballs has not been used optimally. This study
\end{abstract}


aims to determine the potential of breadfruit flour and find the best formulation of breadfruit flour as a filler and binder in beef meatballs. The study was experimental, using a completely randomized design, ie 5 treatments $(0 \%, 10 \%$, $20 \%, 30 \%$, and 40 breadfruit flour) each of 5 replications. Test parameters are chemical tests: water binding capacity (DIA), physical test: resilient power and organoleptic test: colour, texture and taste. Data analysis using Analysis of Variances. The results of the study found that breadfruit flour has the potential to replace tapioca flour as a filler but not as a binder. Breadfruit flour as filler (resilient power) has a very significant effect $(\mathrm{p}<0.01)$; a binder (water binding capacity) has no significant effect ( $p>0.05)$. The best formulation is found in treatment P4 (40\% breadfruit flour).

Key words: Beef meatballs, filler-binder, breadfruit flour (Artocarpus altilis [Parkinson.] Fosberg)

\section{PENDAHULUAN}

Bakso yang memiliki kualitas dan citarasa yang spesifik disukai oleh konsumen. Kualitas dan citarasa bakso dipengaruhi oleh komposisi dan jenis bahan yang digunakan (Purnomo 1998). Produsen melakukan inovasi produk dalam hal: memformulasi komposisi bahan penyusun, membuat produk dengan berbagai variasi rasa dan aman bagi kesehatan konsumen, menekan biaya produksi dengan mengoptimalkan penggunaan sumberdaya lokal. Bahan penyusun bakso selain daging, menggunakan pula berbagai tambahan yang berfungsi sebagai binder (bahan pengikat), filler (bahan pengisi) dan bahan tambahan lainnya. Pada dasarnya bahan yang digunakan sebagai binder dan filler adalah tepung terigu, sedangkan bahan tambahan lainnya dapat berupa garam dapur, bawang putih, dan bahan penyedap (MSG) (Purnomo 1995).

Ketergantungan masyarakat Indonesia pada produk tepung terigu sangat besar. Produksi tepung terigu berasal dari gandum yang sebahagian besar diimpor dan setiap tahun cenderung mengalami kenaikan. Menurut data Badan Pusat Statistik (BPS), ditahun 2016 impor gandum sebesar 10.5 juta ton, ditahun 2017 mengalami kenaikan sebesar $9 \%$ yaitu 11,4 juta ton (Reily 2018), di tahun 2018 Indonesia dinobatkan sebagai negara pengimpor gandum no 1 di dunia menggeser posisi Mesir dengan jumlah impor 12,5 juta ton (Prastaywan 2018). Di sisi lain, Indonesia memiliki sumber pangan lokal yang ketersediaannya melimpah, baik dari segi jenis maupun volume yang belum dimanfaatkan secara optimal untuk menekan penggunaan tepung terigu dan laju impor gandum.

Sukun (Artocarpus altilis [Parkinson.] Fosberg) telah menjadi makanan pokok dan tanaman tradisional di Pasifik selama lebih dari 3000 tahun dan secara luas telah 
dibudidayakan di Karibia dan daerah tropis lainnya (Carrington, Maharaj, and Sankat 2011) termasuk Indonesia, Negara yang beriklim tropis yang kaya akan sumber daya hayati. Sukun (Artocarpus altilis) merupakan tanaman pohon penghasil karbohidrat, tumbuh disekitar 90 negara, bermanfaat sebagai sumber gizi dan obat-obatan, namun belum dikelola secara intensif dan agak terabaikan oleh masyarakat (Ragone 2018; Supriati 2010). Sukun dapat diolah menjadi tepung sukun. Tepung sukun diperoleh dari buah sukun yang diolah melalui proses penepungan Tepung sukun digunakan sebagai produk perantara.Tepung sukun cocok digunakana sebagai bahan dalam pembuatan produk pati seri, sehingga berfungsi sebagai pengganti tepung terigu dalam berbagai pangan olahan (Agustin 2011; Pratiwi, Sulaeman, and Amalia 2012; Ma'ruf, Mustofa, and Suhartatik 2017; Prastaywan 2018). Tepung sukun dapat dijadikan sebagai filler dan binder pada pembuatan bakso karena mengandung karbohidrat dan protein yang tinggi (Agustin 2011). Kandungan karbohidrat yang terdapat dalam tepung sukun terdiri dari amilopektin $77,48 \%$ dan amilosa $22,52 \%$ (Astuti 2009). Amilopektin berperan dalam pelekatan sedangkan amilosa berperan penting dalam kekerasan bakso. Fungsi amilosa yang terdapat pada bakso sebagai komponen perekat akan membentuk tekstur bakso yang baik(Wibowo 1995). Berdasarkan uraian sebelumnya, sukun memiliki beberapa kelebihan, sehingga penelitian ini bertujuan : 1) Mengetahui potensi tepung sukun sebagai filler dan binder dalam bakso daging sapi ; 2) Menemukan formulasi substitusi tepung sukun yang terbaik sebagai filler dan binder dalam bakso daging sapi.

\section{METODE}

\section{Prosedur Penelitian}

Penelitian dilaksanakan pada Bulan Juli 2018 sampai dengan Oktober 2018 di Laboratorium Teknologi Hasil Ternak Jurusan Ilmu Peternakan Fakultas Sains dan Teknologi Universitas Islam Negeri Alauddin Makassar dan Laboratorium Kimia Makanan Ternak Jurusan Nutrisi Ternak Fakultas Peternakan Universitas Hasanuddin Makassar

Alat dan bahan yang digunakan adalah mesin penggiling daging, blender, cawan petri, gelas ukur, cutter, gunting, piring, sendok, talang, talenan, baskom, panci, food prosesing machine, kompor gas, timbangan analitik, kertas grafik, kertas saring, label, plastik glove, plastik klip, tissu, book note, pulpen dan mistar $50 \mathrm{~cm}$, daging sapi segar, sukun (Artocarpus altilis [Parkinson.] Fosberg) diolah menjadi tepung sukun, tepung tapioka, 
bawang merah goreng, bawang putih, merica, garam, es batu, telur, gula pasir. Prosedur penelitiannya yaitu

\begin{tabular}{|c|c|}
\hline \multicolumn{2}{|c|}{ Persiapan Bahan } \\
\hline Pembuatan tepung sukun & Pemilihan daging \\
\hline \multicolumn{2}{|c|}{ Pembuatan Bakso } \\
\hline $\begin{array}{c}\text { Penggilingan tahap } \\
1 \text { dan } 2\end{array}$ & Pencetakan \\
\hline \multicolumn{2}{|c|}{ Pengambilan data } \\
\hline Uji fisik ; Filler (daya lenting) & Uji kimia ;Binder (daya ikat air) \\
\hline \multicolumn{2}{|c|}{ Analisis data } \\
\hline ANOVA & Duncan \\
\hline
\end{tabular}

Gambar 1. Prosedur penelitian Substitusi Tepung Sukun (Artocarpus altilis [Parkinson.]Fosber) sebagai Filler-Binder dalam Bakso Daging Sapi

Rancangan yang digunakan adalah Rancangan Acak Lengkap (RAL) (Creswell 2014; Gasperz 1994) yang terdiri dari 5 perlakuan 5 ulangan.

Tabel 1. Substitusi Tepung sukun (Artocarpus altilis [Park.]Fobs.) Berdasarkan Berat Daging pada Kelima Perlakuan

\begin{tabular}{ccc}
\hline Perlakuan & & Tepung sukun (Artocarpus altilis [Park.]Fobs.) \\
\hline Po & $:$ & $0 \%$ \\
P1 & $:$ & $10 \%$ \\
P2 & $:$ & $20 \%$ \\
P3 & $:$ & $30 \%$ \\
P4 & $:$ & $40 \%$ \\
\hline
\end{tabular}

Variabel yang diamati dalam penelitian ini adalah kemampuan sebagai filler ( daya lenting) dan binder (daya ikat air), yaitu : 
a. Binder $($ Daya Ikat Air $)=\%$ Kadar Air $-\frac{\text { KandunganAirBebas }}{300} \times 100 \%$

$$
\text { Kadar air }(\%)=\frac{W 3}{W 1} \times 100 \%
$$

b. Filler (Daya lenting) = Pengukuran daya lenting dilakukan dengan cara menjatuhkan bakso pada ketinggian dengan menggunakan gelas ukur kaca

\section{Analisis Data}

Analisis data menggunakan Analysis of variances (ANOVA) RAL 5 × 5 uji lanjut menggunakan Uji Duncan.

\section{HASIL DAN PEMBAHASAN}

\section{Uji Kimia: Pengaruh Perlakuan sebagai Binder (Daya Ikat Air) dalam Bakso Daging Sapi}

Pengujian kelima perlakuan sebagai binder (daya ikat air) pada daging dilakukan untuk mengetahui kemampuan daging sebagai bahan utama dan tepung sukun sebagai binder dalam pembuatan bakso daging sapi. Berdasarkan nilai rataaan tepung sukun (Artocarpus altilis [Parkinson.]Fosberg.) sebagai binder (daya ikat air ) dalam bakso daging pada kelima perlakuan bervariasi. Nilai rataan terendah pada perlakuan $\mathrm{P}_{4} ; 40 \%$, tertinggi pada perlakuan $\mathrm{P}_{0} ; 0 \%$, hal ini ditunjukkan pada Gambar 2 .

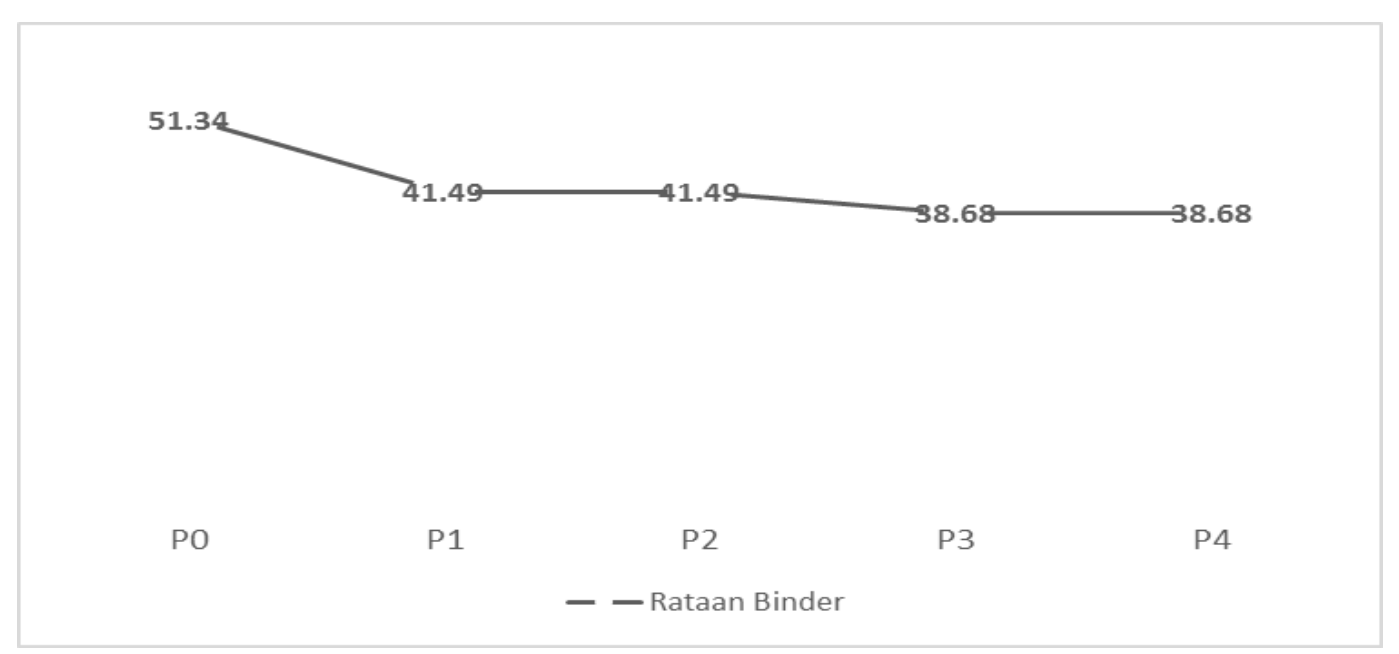

Gambar 2. Grafik rataan tepung sukun (Artocarpus altilis [Parkinson.] Fosberg.) sebagai binder (daya ikat air) dalam bakso daging sapi 
Gambar 2 menunjukkan, bahwa substitusi tepung sukun sebagai binder (daya ikat air) tidak berpengaruh nyata $(p>0,05)$ terhadap bakso daging sapi. Diduga, hal ini disebabkan kandungan protein dalam tepung sukun lebih rendah, mengakibatkan daya ikat airnya menurun. Tepung sukun yang digunakan dalam pembuatan bakso telah mengalami proses pengeringan dan penggilingan, hal inilah yang menyebabkan kandungan protein yang terdapat dalam bahan tersebut mengalami penurunan nilai gizi, akibatnya kemampuan mengikat airnya relatif berkurang. Hal ini sejalan dengan pendapat Domizseuski dkk., (2011), bahwa penurunan daya ikat air disebabkan oleh terjadinya proses denaturasi dan depolimerasi serta peningkatan solubilitas protein karena tekanan dan dan lama perebusan menyebabkan terjadinya kerusakan dan perubahan struktur protein otot terutama pada aktin dan miosin. Kerusakan aktin dan miosin menyebabkan penurunan kemampuan protein otot untuk mengikat air.

Tabel 2. Daftar Sidik Ragam

\begin{tabular}{lccccccc}
\hline \multicolumn{1}{c}{ SK } & DB & JK & KT & F hit & \multicolumn{2}{c}{ F Tabel } \\
\cline { 6 - 8 } & & & & & & 0,05 & 0,01 \\
\hline Perlakuan & 4 & 545,950 & 136,487 & 1,157 & th & 2,866 & 4,431 \\
Galat & 20 & 2,358 & 117,940 & & & & \\
\hline Total & 24 & 2,904 & & & & & \\
\hline
\end{tabular}

Keterangan: $\mathrm{tn}=$ tidak berpengaruh nyata, $\mathrm{P}>0,05$

Semakin meningkatnya persentase substitusi tepung sukun yang diberikan, maka kemampuan tepung sukun sebagai binder ( daya ikat air) terhadap bakso semakin berkurang pula. Hal ini disebabkan, kadar air dalam adonan semakin berkurang, karena rendahnya kandungan kadar air tepung sukun Hal ini didukung oleh (Turi et al. 2015), bahwa persentase kandungan kadar air Artocarpus altilis dan hibirida dalam bentuk tepung lebih rendah (2,5\%-21\%) dibandingkan sukun dalam keadaan segar (19\%-83\%) dan dimasak $(53,2 \%-83,6 \%)$, tetapi persentase bahan keringnya dalam bentuk tepung semakin meningkat (79\% -97\%), sukun keadaan segar (17\%-80,9\%), sukun masak (16,4\%46,8\%). Selanjutnya (Pudjihastuti, 2010) menyatakan, bahwa sukun dapat diolah menjadi tepung, tetapi tepung sukun memiliki karakteristik yang kurang dikehendaki yaitu kurang mengembang dan sedikit mengikat air. Perbaikan kualitas tepung perlu dilakukan supaya pengolahan pangan menjadi lebih luas. Upaya perbaikan kualitas tepung dapat dilakukan dengan memodifikasi 
sifat-sifat fungsional. Modifikasi sebagai perubahan struktur molekul dari pati dapat dilakukan secara kimia, fisika maupun enzimatis

\section{Uji Fisik : Pengaruh Perlakuan sebagai Filler ( Daya Lenting) dalam Bakso Daging Sapi}

Daya lenting merupakan salah satu teknik untuk melihat daya pantul bakso ketika dijatuhkan pada suatu permukaan rata dari suatu ketinggian. Semakin tinggi daya pantul yang dihasilkan, maka kekenyalan bakso semakin baik. Berdasarkan nilai rataaan tepung sukun (Artocarpus altilis [Parkinson.]Fosberg.) sebagai filler (daya lenting ) dalam bakso daging pada kelima perlakuan bervariasi. Nilai rataan terendah pada perlakuan $\mathrm{P}_{3} ; 30$ $\%$, tertinggi pada perlakuan $\mathrm{P}_{4} ; 40 \%$, hal ini ditunjukkan pada Gambar 3

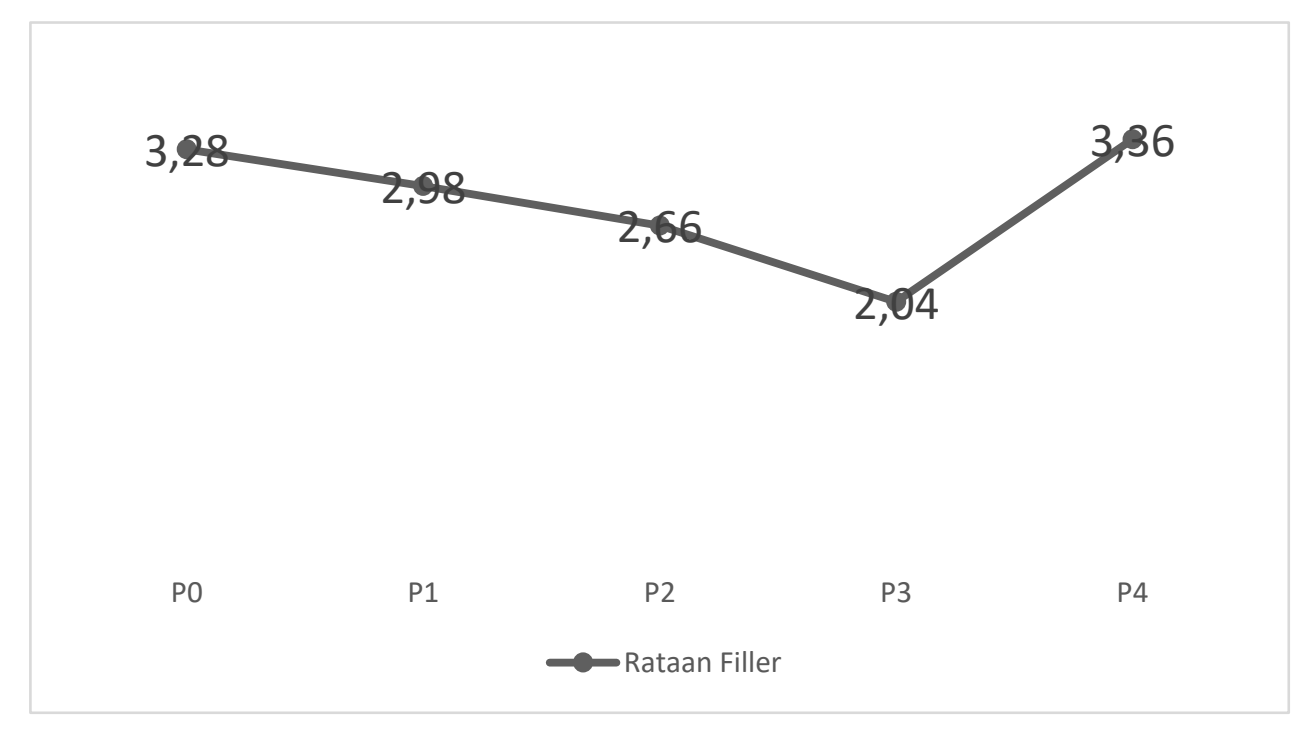

Gambar 3 . Grafik rataan tepung sukun (Artocarpus altilis [Parkinson.]Fosberg.) sebagai filler (daya lenting ) dalam bakso daging sapi

Hasil analisis ragam pada Tabel 3 menunjukkan, bahwa substitusi tepung sukun sebagai filler dan binder dalam bakso sapi memberikan pengaruh sangat nyata $(p<0,01)$ terhadap nilai daya lenting bakso., artinya penggunaan tepung sukun sebagai filler mampu mempertahankan nilai daya lenting bakso. Hal ini dapat disebabkan karena amilopektin pada sukun yang tinggi mampu mempertahankan nilai elastisitas dan berperan dalam kerekatan bakso. 
Tabel 3. Daftar Sidik Ragam

\begin{tabular}{lccccccc}
\hline \multicolumn{1}{c}{ SK } & DB & JK & KT & F hit & \multicolumn{2}{c}{ F Tabel } \\
\cline { 5 - 8 } & & & & & & 0,05 & 0,01 \\
\hline Perlakuan & 4 & 5,766 & 1,441 & 6,418 & $* *$ & 2,866 & 4,431 \\
Galat & 20 & 4,492 & 0,225 & & & & \\
\hline Total & 24 & 10,258 & & & & & \\
\hline
\end{tabular}

Keterangan: ** berpengaruh sangat nyata $\mathrm{P}<0,01$

Tabel 4. Hasil Analisis Uji Duncan Perbedaan antar Perlakuan Sebagai Filler (Daya Lenting) dalam Bakso Daging Sapi

\begin{tabular}{cccc}
\hline Perlakuan & & Tepung sukun (Artocarpus altilis [Park.]Fobs.) & Signifikansi $(0,01)$ \\
\hline Po & $:$ & $0 \%$ & $\mathrm{a}$ \\
P1 & $:$ & $10 \%$ & $\mathrm{a}$ \\
P2 & $:$ & $20 \%$ & $\mathrm{~b}$ \\
P3 & $:$ & $30 \%$ & $\mathrm{~b}$ \\
P4 & $:$ & $40 \%$ & $\mathrm{~b}$ \\
\hline
\end{tabular}

Sumber: Data Primer Setelah Diolah, 2018.

Hasil analisis pada Tabel 4 menujukkan adanya perbedaan sangat nyata antar perlakuan, namun perlakuan $\mathrm{P}_{4}: 40 \%$ menunjukkan daya lenting yang paling tinggi dari kelima perlakuan. Hal ini disebabkan kandungan amilopektin yang tinggi, seiring dengan jumlah konsentrasi yang digunakan lebih banyak dibandingkan perlakuan lainnya. Kondisi ini menunjukkan, penggunaan jenis dan jumlah tepung dapat mempengaruhi elastisitas bakso.

\section{KESIMPULAN}

1. Tepung sukun memiliki potensi menggantikan tepung tapioka sebagai filler (daya lenting) berpengaruh sangat nyata $(\mathrm{p}<0.01)$, namun tidak sebagai binder (daya ikat air), karena tidak berpengaruh nyata $(p>0.05)$ dalam pembuatan bakso daging sapi.

2. Formulasi substitusi tepung sukun (Artocarpus altilis [Parkinson.]Fosberg.) sebanyak $40 \%$ merupakan formulasi yang terbaik untuk memperoleh kekenyalan yang baik dalam pembuatan bakso daging sapi. 


\section{DAFTAR PUSTAKA}

Agustin, S. 2011. Kajian pengaruh hidrokoloid dan $\mathrm{CaCl}_{2}$ terhadap profill gelatinisasi bahan baku serta aplikasinya pada bihun sukun. Tesis. Sekolah Pascasarjana Institut Pertanian Bogor, Bogor

Astuti, dan Fuji, E. 2009. Pengaruh jenis tepung dan cara pemasakan terhadap mutu bakso dari surimi ikan hasil tangkap sampingan ( HTS ). Skripsi. Fakultas Perikananan dan Ilmu Kelautan Institut Pertanian Bogor, Bogor.

Carrington, C.M.S., Maharaj, R., and Sankat, C.K. 2011. Postharvest Biology and Technology of Tropical and Subtropical Fruits Breadfruit (Artocarpus altilis [Parkinson] Fosberg). Woodhead Publishing Co, UK.

Creswell, J.W. 2014. Research Design: Pendekatan Kualitatif,Kuantitatif dan Mixed. Edisi keti. ed. Achmad Fawaid. Pustaka pelajar, Yokyakarta.

Gasperz, V. 1994. Metode Perancangan Percobaan. Armico, Bandung.

Ma'ruf, F.H.., Mustofa A., dan Suhartatik, N. 2017. Pemanfaatan tepung sukun (Artocarpus communis) dalam pembuatan tortilla dengan variasi penambahan jagung (Zea mays) dan kacang hijau (Vigna radiata). Jurnal Teknologi dan Industri Pangan 2(2),126-133.

Prastaywan, N. 2018. Impor gandum indonesia mulai mengkhawatirkan! saatnya berubah!" Kadin Jawa Timur. https:/ / kadinjateng.com/impor-gandum-indonesia-mulaimengkhawatirkan-saatnya-berubah/ (18 July 2018).

Pratiwi., Putri, D., Sulaeman, A., dan Amalia, L. 2012. Pemanfaatan tepung sukun (Artocarpus altilis sp.) pada pembuatan aneka kudapan sebagai alternatif makanan bergizi untuk PMT-AS. Jurnal Gizi dan Pangan, 7(3): 175-80.

Purnomo, H. 1995. Pengaruh Air Dan Peranannya Dalam Pengawetan Pangan. Edisi1 ed. Universitas Indonesia (UI-Press).

- - - . 1998. Teknologi Hasil Ternak Kaitannya dengan Keamanan Pangan Menjelang Abad 21. Pidato Pengukuhan Guru Besar Dalam Ilmu Teknologi Hasil Ternak pada Fakultas Peternakan. Universitas Brawijaya, Malang.

Ragone, and Diane. 2018. Breadfruit-Artocarpus altilis (Parkinson) Fosberg. In exotic fruits. Elsevier, 53-60.

Reily, M. 2018. Impor Gandum Melonjak Pesat, Pengawasan Diperketat. Katadata Market Sentimen Index. https:/ / katadata.co.id/ berita/2018/02/23/impor-gandum-melonjakpesat-pengawasan-diperketat ( 18 juli 2018)

Supriati, Y. 2010. Sukun sebagai sumber pangan alternatif substitusi beras. Jurnal Iptek Tanaman Pangan 5 (Pangan Alternatif): 219-31.

Turi., Christina E., Liu, Y., Ragone, D., and Murch, S.J. 2015. Breadfruit (Artocarpus altilis and Hybrids): A traditional crop with the potential to prevent hunger and mitigate diabetes in oceania. Trends in Food Science and Technology, 45(2), 264-72.

Wibowo, S. 1995. Pembuatan Bakso Ikan dan Bakso Daging. Penebar Swadaya, Jakarta. 